\title{
Effect of Fermentation on the Microbial and Nutrient Composition of Digue: A Fermented Food Obtained with Pumpkin (Cucurbita maxima) and Peanut (Arachis hypogaea)
}

\author{
Tchikoua Roger* Etoundi Abanda Simon Wilfred Sado Kamdem Sylvain Leroy \\ Essia Ngang Jean Justin \\ Department of Microbiology, Faculty of Science, the University of Yaounde 1, P.O. Box 812, Yaoundé, \\ Cameroon
}

\begin{abstract}
The aim of this work was to study the evolution of microbiological and selected physicochemical parameters during the production of Digue, food obtained from the addition of the paste of roasted Arachis hypogaea (peanuts) in Yam Digue, fermented juice of Cucurbita maxima (pumpkin). The evolution of the microbial flora, the content of reducing sugars, total polyphenols, phosphorus, potassium and titratable acidity were measured during 30 days. Microbiological analysis at the start of fermentation revealed the presence of 03 groups of pathogenic germs such as staphylococci, enterobacteria and moulds with concentrations of 3.2, 3.8 and 3.24 $\log _{10} \mathrm{CFU} / \mathrm{ml}$ respectively. We also observed the presence of lactic acid bacteria (LAB) which were are the most represented bacterial flora in the medium with a microbial load of $5.2 \log _{10} \mathrm{CFU} / \mathrm{ml}$. During fermentation, enterobacteria, staphylococci and moulds respectively reached maximum values of 3.2, 3.8 and $3.2 \log _{10} \mathrm{CFU} / \mathrm{ml}$ on the $7^{\text {th }}$ day. However, after the $21^{\text {st }}$ day, enterobacteria and mould were eliminated, unlike staphylococci which were completely inhibited only on the $28^{\text {th }}$ day. The highest phosphorus and potassium contents were recorded on the $21^{\text {st }}$ day with values of $0.29 \%$ and $2.5 \%$ respectively. On the $14^{\text {th }}$ day, the LAB yielded much higher microbial concentration of $8.9 \log _{10} \mathrm{CFU} / \mathrm{ml}$ which also led to the optimum production of titratable acidity $(1.2 \%)$ in the medium. During the same period, the sugar content increased by $2.3 \%$ and the polyphenols were eliminated at $100 \%$. The data obtained in this work reveal the elimination of microbial growth and increasing the physicochemical qualities at the $21^{\text {th }}$ day with fermentation. Thus, it would be recommended for producers to ferment it for over 21 days as result of appreciable yield in terms of microbial, organoleptic and chemical qualities.
\end{abstract}

Keywords: Cucurbita maxima, Digue, fermentation, nutritional, pathogenic germs

DOI: $10.7176 / \mathrm{FSQM} / 103-05$

Publication date: December $31^{\text {st }} 2020$

\section{Introduction}

Spontaneous fermentation is considered as a method of food processing and preservation (llesanmi and Opeyemi, 2017). During this fermentation process, many changes regarding microbial and physicochemical qualities are recorded (Dominic et al., 2019). The products obtained after fermentation are numerous and varied depending on the diversity of the raw materials, the microbial flora and the production process used (Ogodo et al., 2019). All these parameters contribute intensively to the final quality of the expected product. Several studies have highlighted the influence of fermentation on certain local fermented foods in Africa. For instance, the study of Ojokoh and Orekoya (2016) showed increase in proteins (3.5\%), lipids (0.6\%) and titratable acidity as compared to the control after 96 hours of fermentation of Citrullus lanatus. In addition, Ejinkeonye et al. (2018) observed an increase in proteins (1.9\%) and a reduction in lipids, tannins, phytates and saponins by $88.57 \%, 72.09 \%$ and $75 \%$ respectively in the watermelon seeds after 120 hours of fermentation. Moreover, the work carried out by Makawi et al. (2019) revealed that during the fermentation of Adamsonia digitata over 36 hours, an increase in potassium (K) (from 547 to $665 \mathrm{mg} / 100 \mathrm{~g}$ ), calcium (Ca) (240 to $260 \mathrm{mg} / 100 \mathrm{~g}$ ), magnesium (Mg) (453 to 500 $\mathrm{mg} / 100 \mathrm{~g})$ and iron $(\mathrm{Fe})(5.01$ to $5.83 \mathrm{mg} / 100 \mathrm{~g})$. They also noted an increase in the microbial load of yeasts and moulds after 24 hours of fermentation wish a subsequent decrease after 36 hours. Furthermore, Abiola and Ekunrin (2016) have shown that the bacterial population increases significantly $(\mathrm{p}<0.05)$ in the melon (Cucumis melo L.) husk from $12 \times 10^{3}$ to $37 \times 10^{3} \mathrm{CFU} / \mathrm{g}$ after 72 hours of fermentation.

In the Northern part of Cameroon, particularly in Gamboura, many fermented foods are produced such as Digue, which is obtained from the addition of roasted peanut paste in the Yam Digue, a fermented melon juice. Digue finds its popularity in its low cost of production and also in its special organoleptic qualities which, like cheese and soy sauce, develop during the long maturation period of 30 days. During this maturation, the Digue acquires aromas and a pronounced taste, therefore the intensity varies with time. Regularly consumed by the population, it is produced during all the seasons and can be stored in dried form for more than one year. Thanks to its energy value, long storage time and short cooking time $(20-30 \mathrm{~min})$, it is the ideal food for subsistence in the dry season. Traditionally, the Digue is present during the festivities and constitutes for women who have just 
given birth an essential food for their recovery. As a result of the aforementioned, it can be seen that Digue occupies an important place in this region of the country. However, no study has been conducted to date in order to evaluate physicochemical and microbiological parameters during spontaneous fermentation of Digue. Hence, this study was aimed at assessing the changes in titratable acidity, polyphenols, available sugars, selected minerals and microbial flora of Digue during fermentation.

\section{Material and methods}

\subsection{Sampling site and sample collection}

Pumpkins and peanuts utilised for the preparation of the Digue were collected at the Gamboura periodic market. Gamboura is located in the Far North region of Cameroon, precisely in the Mayo-Tsanaga division, Bourha subdivsion whit Mokolo as its main town.

$5 \mathrm{~kg}$ of peanuts and pumpkin fruit for a total weight of $2 \mathrm{~kg}$ were purchased. These materials were transported in PVC bag. Samples were transported under aseptic conditions to the National Herbarium of Cameroon for identification and then to the microbiology laboratory for the preparation of the Digue.

\subsection{Digue production}

After washing, the pumpkins are deeping in water containing chlorine $(\mathrm{NaOCl})$ at 200ppm for 3 min (Silomona et al., 2018) and rinsed with distilled water. The fruits were sliced and mixed with water at a ratio of $1: 1.5(\mathrm{~W} / \mathrm{V})$. The mixture was covered and stored for 04 weeks at room temperature $\left(25 \pm 2{ }^{\circ} \mathrm{C}\right)$. This first stage of preparation of the Digue allowed the fermentation of the pumpkin slices. This fermentation thus participates in the beginning of changes in the nutritional, organoleptic and physicochemical parameters of this food. After 28 days of fermentation, the preparation obtained was stirred in the container and then sieved using a sieve with pore diameter of $0,9 \mathrm{~mm}$. The sieving process permitted removal of all solid residues contained in the product. The liquid obtained from this filtration called Yam Digue was mixed with the roasted peanut paste in the proportions 1/0.5 (V/W). The mixture, called the Digue, was left to stand for 2 days maturation. The figure 1 shows the Digue production diagram.

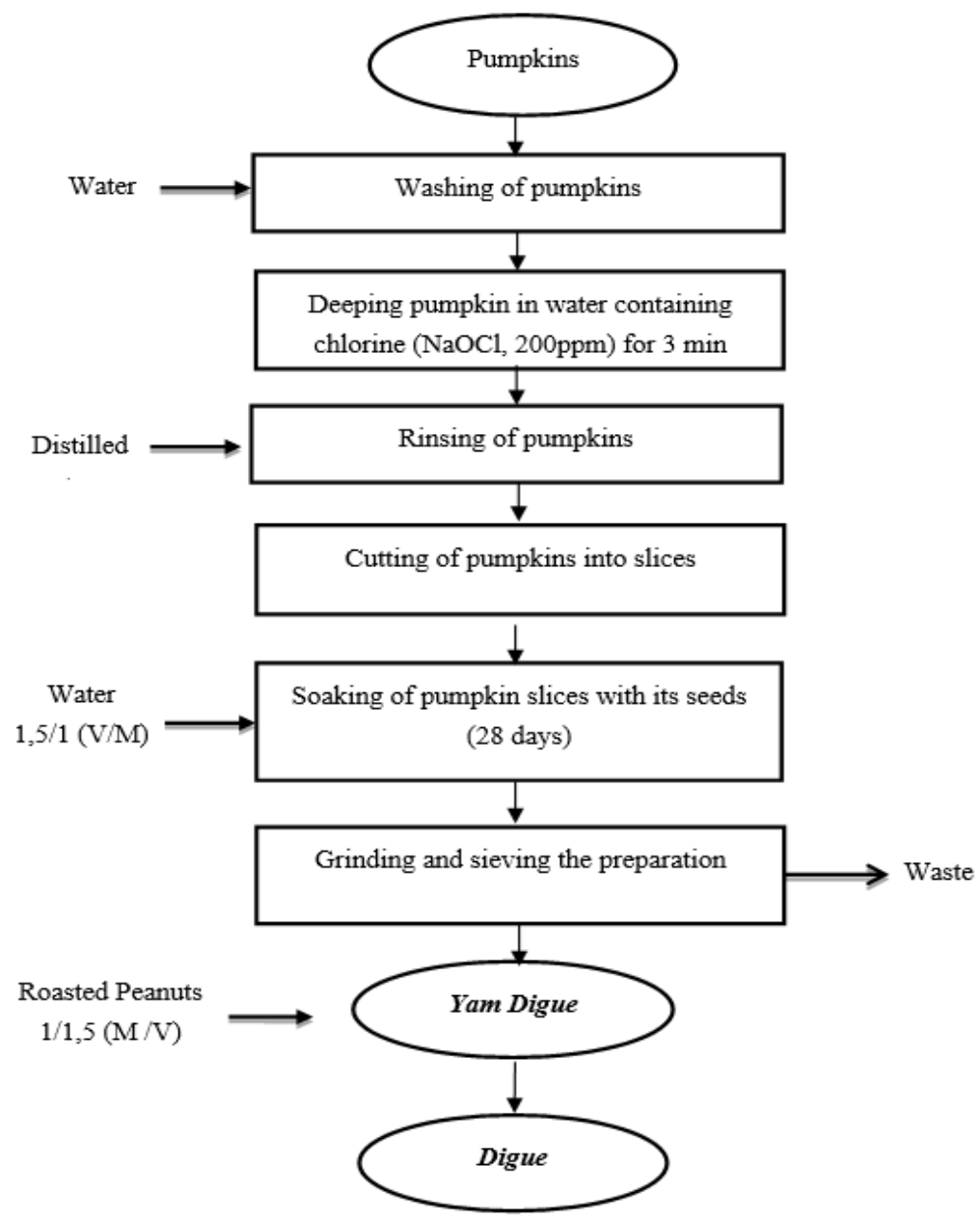

Figure 1. The flow diagram of production of Digue 


\subsection{Microbiological analysis during production of Digue}

To carry out microbial analysis, $25 \mathrm{ml}$ of the sample was diluted in $225 \mathrm{ml}$ of sterile saline water for the preparation of the first dilution and successive dilutions were made up to $10^{-10}$ dilution. $0.1 \mathrm{ml}$ of each dilution was seeded by plate spreading on Nutrient Agar (NA), Eosin Methylene Blue Agar (EMB), Mannitol Salt Agar, Potato Dextrose Agar (PDA) and De Mann, Rogosa and Sharpe Agar (MRS) supplemented with benzimidazole in order to enumerate the total aerobic mesophilic flora, enterobacteria, Staphylococci, mould and lactic acid bacteria respectively. MRS agar plates were incubated in anaerobic conditions in jar and together with the other media for bacterial isolation. The incubation was done at $37^{\circ} \mathrm{C}$ for $24-48$ hours. Regarding the moulds, the dishes with PDA were incubated at $25^{\circ} \mathrm{C}$ for 3 to 5 days.

\subsection{Chemical analysis during production of Digue \\ 2.4.1. Determination of reducing sugars}

The sugar content in the Digue was measured according to the method described by Dubois et al. (1956). For the extraction of sugars, $0.5 \mathrm{~g}$ of the sample was introduced into a test tube containing $5 \mathrm{ml}$ of sulfuric acid $(1.5 \mathrm{~N})$. The mixture was heated at $100^{\circ} \mathrm{C}$ for $45 \mathrm{~min}$ in a water bath and then cooled to room temperature. After these operations, $10 \mathrm{ml}$ of ethanol $(70 \%), 1 \mathrm{ml}$ of zinc acetate $(2 \mathrm{~g} / 100 \mathrm{ml})$ and $1 \mathrm{ml}$ of potassium ferrocyanide $(10.6 \mathrm{~g} / 100 \mathrm{ml})$ were added. The mixture was then filtered into a $50 \mathrm{ml}$ flask and the volume adjusted to the gauge line.

After extraction, $0.375 \mathrm{ml}$ of extract was mixed with $0.5 \mathrm{ml}$ of phenol (5\%), $4.625 \mathrm{ml}$ of distilled water and $2.5 \mathrm{ml}$ of concentrated $\mathrm{H}_{2} \mathrm{SO}_{4}$ in a test tube. After storage for 10 minutes at room temperature $\left(25 \pm 2{ }^{\circ} \mathrm{C}\right)$, the mixture was well homogenized and then brought to a water bath maintained at $100^{\circ} \mathrm{C}$ for $20 \mathrm{~min}$. An orange coloration developed in the course of the reaction and the optical density was read using a spectrophotometer (Jeanway, 6305) at $490 \mathrm{~nm}$ against a blank (free of the sample and prepared under the same conditions). The sugar content in the samples was determined by reference to a range of glucose standard $(1 \mathrm{mg} / \mathrm{ml})$ and referring to the regression equation calibration curve: $\mathrm{Y}=0.47 \mathrm{X}+0.53\left(\mathrm{R}^{2}=0.99\right)$. Where $\mathrm{Y}$ is OD (optical density) and $\mathrm{X}$ is reducing sugars. The sugar content was expressed in $\mathrm{g} / 100 \mathrm{~g}$ of dry matter.

\subsubsection{Determination of total polyphenols during Digue production}

The total polyphenols were determined according to the method of Marigo (1973). For that, 1ml of sample was added to $40 \mathrm{ml}$ of acetone $(80 \%)$. The mixture obtained was left for 24 hours and filtered through Whatman paper (No. 41) three times. For the assay, $6 \mathrm{ml}$ of distilled water was added to $100 \mu \mathrm{l}$ of extracts. Then $1.5 \mathrm{ml}$ of sodium monocarbonate $(20 \%)$ and $0.5 \mathrm{ml}$ of Folin-Ciocalteu were added to the extract. The mixture obtained was adequately stirred and adjusted to $10 \mathrm{ml}$. After 2 hours of incubation at room temperature $\left(25 \pm 2^{\circ} \mathrm{C}\right)$ in the dark, absorbance was measured at $760 \mathrm{~nm}$. The total polyphenols content was determined by referring to the equation of the calibration curve $\mathrm{Y}=0.04 \mathrm{X}+0.22\left(\mathrm{R}^{2}=0.89\right)$. Where $\mathrm{Y}$ is OD (optical density) and $\mathrm{X}$ is total polyphenols. The calibration line was carried out using a gallic acid solution and the polyphenol content was expressed in $\mathrm{mg} / 100 \mathrm{~g}$.

\subsubsection{Determination of potassium}

Potassium was determined by atomic absorption spectrophotometry (Pauwels et al., 1992).

\subsubsection{Determination of phosphorus}

The phosphorus content was carried out by UV-visible spectrophotometry (Pauwels et al., 1992). The intensity of the colour at the end point is measured at $610 \mathrm{~nm}$ on a UV-visible single-beam grating spectrophotometer (jenway 6305).

\subsection{Titratable acidity determination}

The titratable acidity was determined by titration of the filtrate obtained from $10 \mathrm{~g}$ of the sample mixed with $100 \mathrm{ml}$ of distilled water. The titration acidity was carried out with a $0.1 \mathrm{~N}$ sodium hydroxide $(\mathrm{NaOH})$ solution in the presence of 3 drops of a $1 \%$ phenolphthalein solution used as indicator. The acidity was expressed in $\mathrm{g}$ of lactic acid (MW $=90.08 \mathrm{~g} / \mathrm{mol}$ ) per $100 \mathrm{~g}$ of the sample (Obadina et al., 2010).

\subsection{Statistical analysis}

The results obtained were analysed using Statgraphics 5.0 software for analysis of variances, calculation of means and standard deviations. Sigma Plot 11.0 software use for graphical representation of data.

\section{Results and discussion}

\subsection{Change in microbial growth}

Microbiological analysis (figure 2) of the Digue samples at the start of the fermentation permitted detection of 04 groups of microorganisms namely, enterobacteria, staphylococci, LAB and moulds. LAB were the most represented with a load of $5.2 \log _{10} \mathrm{CFU} / \mathrm{ml}$ and these were followed by staphylococci, moulds and enterobacteria with respective loads of $\left.3.9 \log _{10} \mathrm{CFU} / \mathrm{ml}\right), 3.3 \log _{10} \mathrm{CFU} / \mathrm{ml}$ and $3.3 \log _{10} \mathrm{CFU} / \mathrm{ml}$. Durıng the 
fermentation process that was conducted over 30 days, the microbial growth varied from one group of microorganisms to another. For example, after 7 days of fermentation, the enterobacteria and mould concentration increased respectively by $2.3 \log _{10} \mathrm{CFU} / \mathrm{ml}$ and $2.6 \log _{10} \mathrm{CFU} / \mathrm{ml}$ while Staphylococci recorded the highest growth increase estımated to $3 \log _{10} \mathrm{CFU} / \mathrm{ml}$ after 7 days of fermentation. This growth could be explained by the rich nutritional composition of Cucurbita maxima that can be used by LAB, enterobacteria, staphylococci and moulds for their growth. Indeed, the pulp of the Cucurbita maxima is rich in dietary fibers, bioactive compounds, b-carotene, vitamin A and tocopherol (Wang et al., 2002; Zhang et al., 2000), other vitamins (B, K, C, thiamine, and riboflavin) as well as K, P, Mg, Fe, Se (Nawirska et al., 2009) and protein (Ponka et al., 2015)

Despite the nutritional composition of the Cucurbita maxima, which promoted the growth of pathogenic germs during the first 7 days of fermentation, a total deactivation in growth was observed for enterobacteria and moulds after the 21 days of fermentation. Staphylococci, which were more resistant, were totally deactivated only after 28 days of fermentation. The reduction of growth of these different microorganisms could be explained by the presence of certain antimicrobial elements produced during fermentation such as bacteriocins, organic acids which are the main products of lactic acid metabolism (Liu, 2003).

In fact, a reduction was observed when the amount of acid produced in the Digue reached an optimum of $1.2 \%$. Many studies have also highlighted this phenomenon. Adulkadir and Danjuma (2015) observed a reduction in enteric bacteria from $7 \times 10^{4} \mathrm{CFU} / \mathrm{ml}$ to $10 \mathrm{CFU} / \mathrm{ml}$ during the fermentation of a cereal-based weaning food enriched with soy and tiger nuts. Abiola and Oyetayo (2016) also noted an absence of Staphylococcus in the medium when the concentration of organic acids increased during the fermentation of kersting peanuts. The correspondence of LAB growth pick and titrable acidity pick indicate that, the LAB may be responsible for organic acid and antimicrobial compound production.

The ability of LAB to resist and multiply in an acid environment could be explained by their ability to tolerate acid. Indeed, acidity tolerance is a mechanism aimed at reducing the effects of intracellular accumulation of protons by expelling from the intracellular medium, neutralizing them or repairing the damage caused by these protons (Drider and Prévoste, 2009). Contrary to the inhibition of certain pathogens observed on the $14^{\text {th }}$ day, we observed an increase in LAB concentration when acidity reached $1.2 \%$. The work carried out by Tchikoua (2016) has shown that Lactobacillus buchneri M11 and Lactobacillus fermentum N25 continued to multiply despite the high concentration of organic acids during fermented paste obtained from maize. However, the increase in the concentration of LAB observed on the $30^{\text {th }}$ day could be attributed to the addition of peanuts on the $28^{\text {th }}$ day of fermentation. This has been observed by Boudjelal and Nancib (2001). The latter noted that, after adding date juice to the culture media, an increase of $2.24 \mathrm{~g} / \mathrm{ml}$ of biomass was observed.

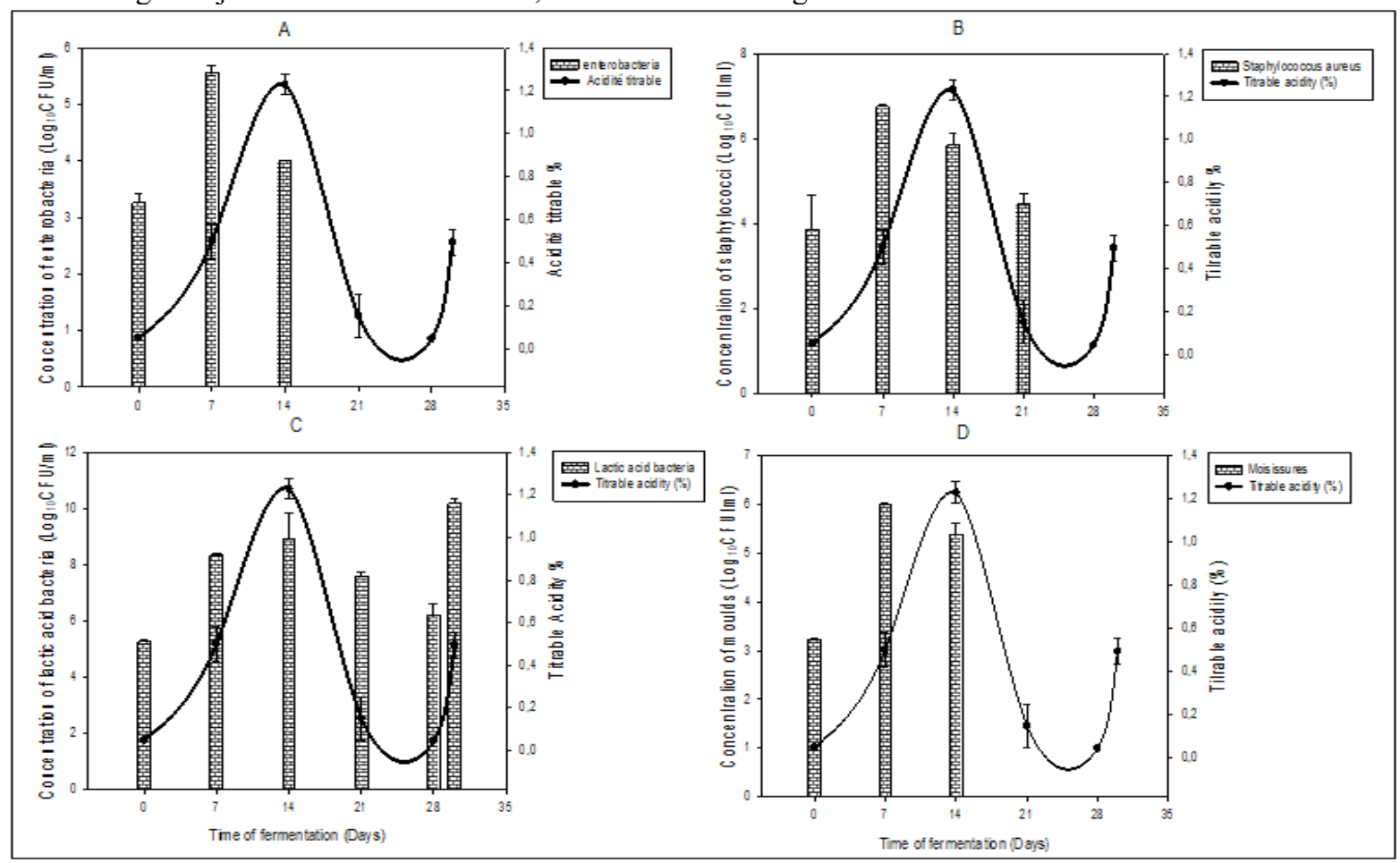

Figure 2. Change in enterobacteria (A), Staphylococci (B), Lactic acid bacteria (C), Moulds (D) and titratable acidity during the fermentation of the Digue. 


\subsection{Change of selected parameters during the fermentation of the Digue.}

\subsubsection{Determination of reducing sugars}

Figure 3 shows the change in the reducing sugar content available during the production of the Digue. During fermentation, there is a fluctuation in the evolution of the reducing sugar content. At the start of fermentation and after the $7^{\text {th }}$ day, there is a slight decrease in the content of reducing sugars ranging from 1.5 to $1.2 \%$. The decrease in the reducing sugar content observed could be explained firstly by the metabolic needs of microorganisms. From the $7^{\text {th }}$ to $21^{\text {th }}$ day of fermentation, there is an increase in the content of the reducing sugars ranging from 1.2 to $2.3 \%$ two times higher than the initial content. This increase is followed by a decrease on the $28^{\text {th }}$ day of around $1 \%$, an increase in the content of the reducing sugars of about $3.1 \%$. Once these reducing sugars are used, the LAB direct their needs toward complex sugars to continue producing the energy necessary for their growth. During this process of degradation of complex sugars, reducing sugars are released and this could certainly explain the increase in sugars available between the $7^{\text {th }}$ and the $21^{\text {st }}$ day of fermentation. In addition, the inequality between the low rate of use of simple sugars when they are produced and the high rate of degradation of complex sugars could also explain this increase in simple sugars during fermentation. However, the high concentration of sugar observed on the $30^{\text {th }}$ day could be explained by the addition of peanuts in the Yam Digue. We can noted that, 100g of dry-roasted peanuts contain 4.18g of sugar (Settaluri et al., 2012).

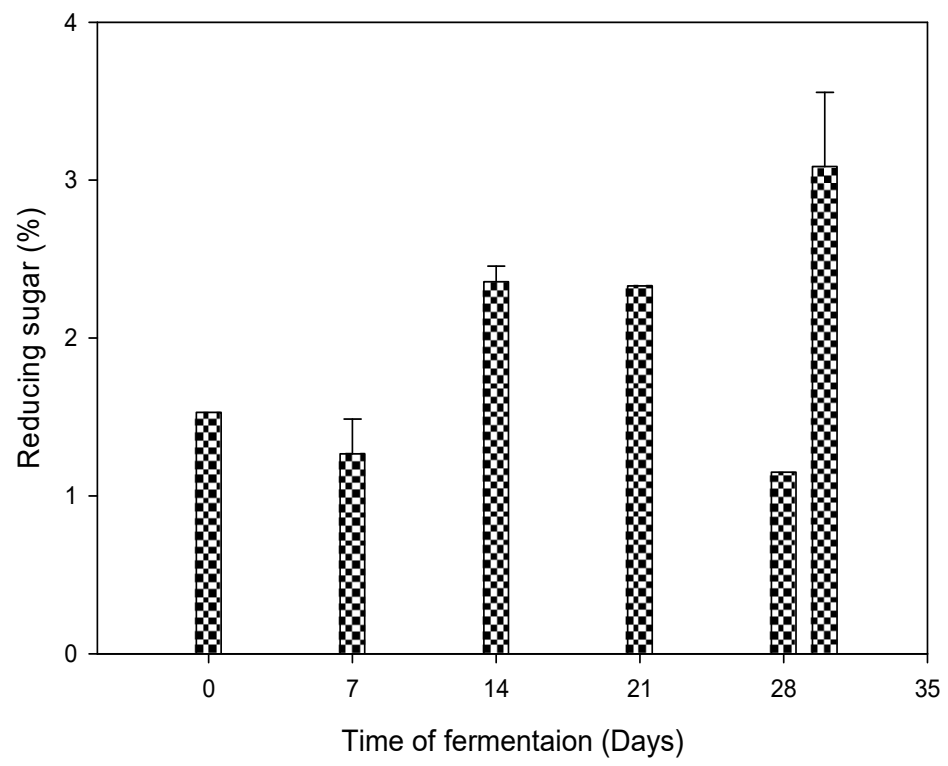

Figure 3. Change in the reducing sugars content available during the production of the Digue.

\subsubsection{Determination of total polyphenols}

The determination of the polyphenols in the pumpkin before fermentation revealed that it contained a high concentration of polyphenols estimated at $35 \mathrm{mg} / 100 \mathrm{~g}$ (figure 4). After 14 days of fermentation, all polyphenols were eliminated. The total elimination of total polyphenols could be explained by the production of polyphenol oxidases by LAB which hydroxylate monophenol molecules into phenol molecules containing two hydroxyl groups during fermentation (Awada et al., 2005). Mohamed et al. (2007) also observed a reduction of 50 $\mathrm{mg} / 100 \mathrm{~g}$ DM of total polyphenols in millet of cultivar "Gazira" and of $30 \mathrm{mg} / 100 \mathrm{~g}$ MS in millet of cultivar "Gadarif" after 24 hours of spontaneous fermentation at $37^{\circ} \mathrm{C}$. Adam et al. (2010) noted a reduction in polyphenol contents ranging from 120.4 to $111.08 \mathrm{mg} / 100 \mathrm{gMS}$ during millet fermentation. This reduction in total polyphenols is beneficial for the consumer because it increases the availability of minerals and proteins in fermented foods (Tchikoua, 2016). However, an increase $(12.5 \mathrm{mg} / 100 \mathrm{~g})$ in total polyphenols was observed from the $30^{\text {th }}$ day and this increase could be related to the addition of peanuts which are an important source of polyphenols. Indeed, peanuts may have a total polyphenol content of $38.5 \mathrm{mg}$ of gallic acid equivalent/g of dry weight (Amar et al., 2015). 


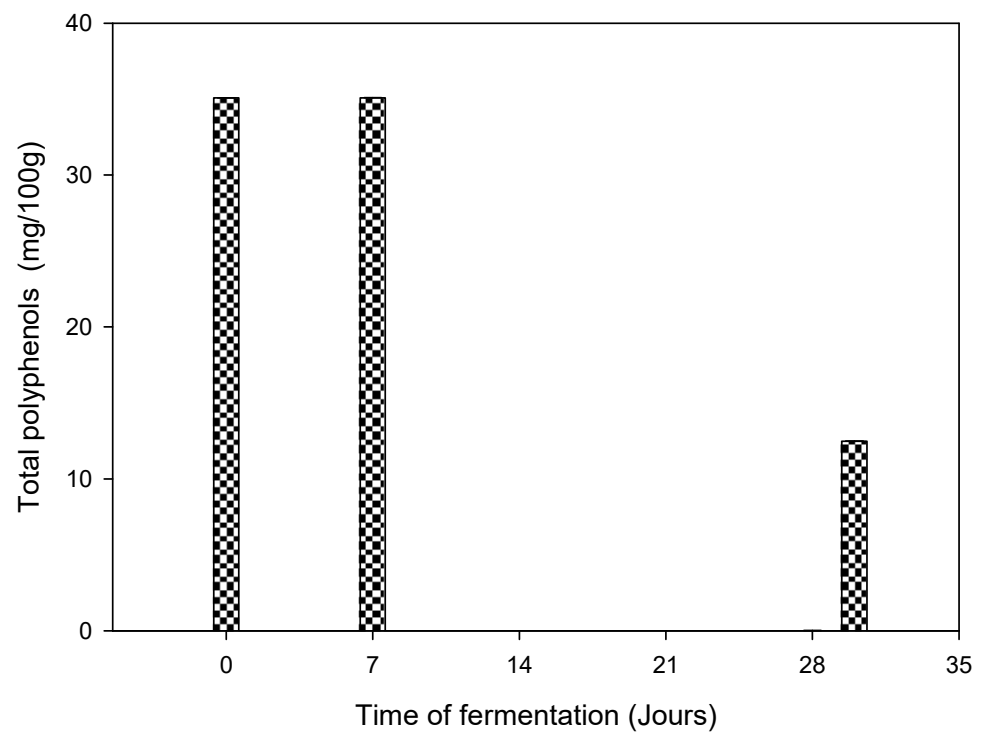

Figure 4. Change of total polyphenols content during the production of the Digue.

\subsubsection{Determination of minerals content}

Regarding potassium, there is an increase of about $0.6 \%$ between the first day and the $7^{\text {th }}$ day of fermentation. We also note the increase in phosphorus of about $0.14 \%$ in same period. The increase in the mineral content could be explained by the decrease in the total polyphenol content, thus, increasing the availability of minerals during fermentation. Studies by Makinde and Akinoso (2013) have shown an increase in phosphorus and potassium after the $7^{\text {th }}$ day of fermentation of sesame seeds. Mohamed et al. (2007) noted an increase $(22 \mathrm{mg} / 100 \mathrm{~g})$ of phosphorus during the millet fermentation. After 30 days of fermentation, a maximum phosphorus content of $3.6 \%$ was observed and a decrease of $1.8 \%$ of potassium was recorded. This reduction in potassium can be explained by a dilution of the Yam Digue potassium by the peanut. Furthermore, it is also possible that this reduction in potassium is due to the complexation of potassium ions by the free fatty acids provided by peanuts to form a potassium salt of fatty acids. The increase of phosphorus could be explain by the association of phosphorus contained in peanuts $(0.4 \mathrm{~g} / 100 \mathrm{~g}$ of dry-roasted peanuts) (Settaluri et al., 2012) with phosphorus already present in Yam Digue will increase the phosphorus content of Digue. Figure 5 shows the change of minerals during the fermentation of the Digue.

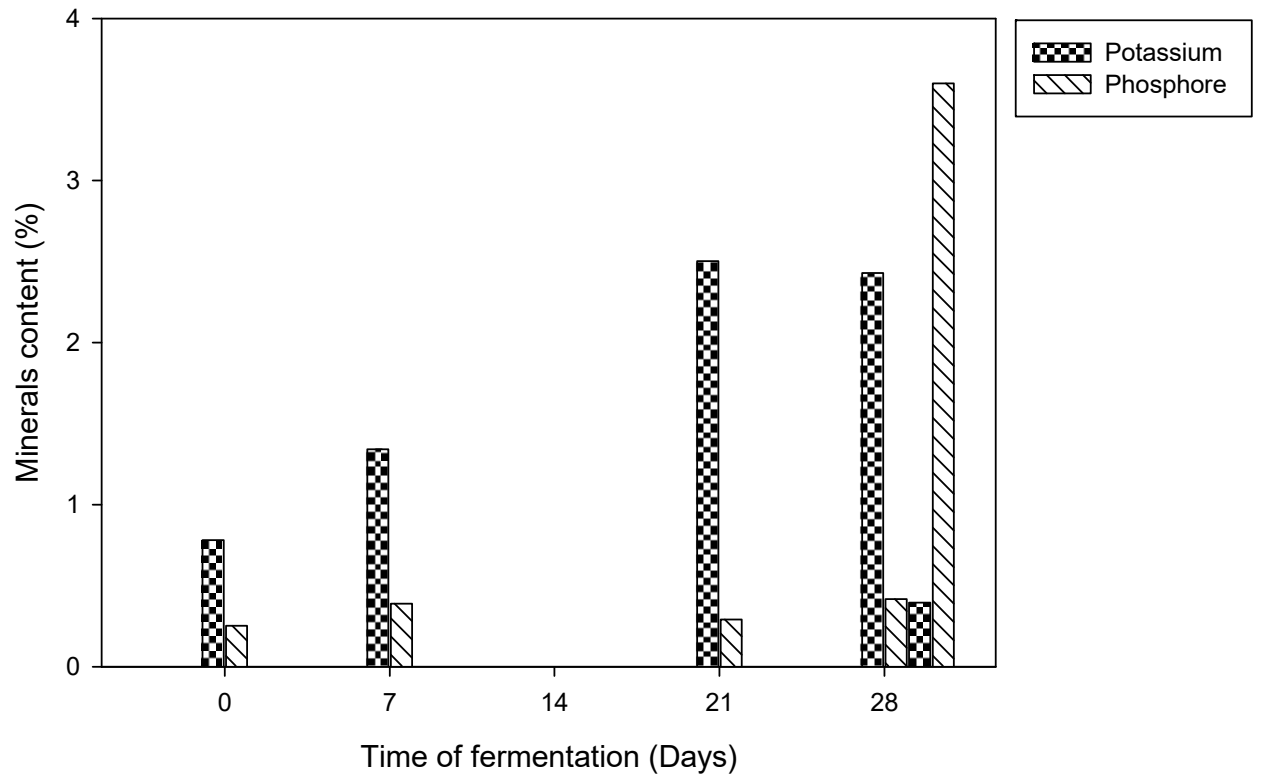

Figure 5. Change of minerals during the fermentation of the Digue

\section{Conclusion}

This is the first report on the study of Digue. During spontaneous fermentation of this product initially observed 
pathogens like, enterobacteria and mould are deactivated on the $21^{\text {th }}$ days. On the physicochemical point of view, many variation are observed during fermentation with final values of $1.2 \%$ (the titratable acidity), $2.3 \%$ (reducing sugars), $2.5 \%$ (potassium) and $0.29 \%$ (phosphorus). In addition, we note total reduction of polyphenols. The results obtained in this work permit to recommend to producers, the fermentation of Digue at least 21 days and the observation of good hygiene practices during this production.

\section{References}

Abiola, C. \& Ekunrin, M.F. (2016), "Effect of fermentation on the microbial, nutrient and anti-nutrient contents of melon (Cucumis melo L.) Husk", Microbiology Journal 6, 9-14.

Abiola, C. \& Oyelayo O.V. (2016), "Isolation and biochemical charactérisation of microorganisms associated with the fermentation of Kersting's Groundnut Macrotyloma geocarpum", Resaerch journal of Microbiology 11(2-3), 47-55.

Adam, I.A., Abdalla, A.A., Khalid, A.I. \& El-Tinay, A.H. (2010), "Effect of Traditional Processing on Phosphorus Content et Some Anti Nutritional Factors of Pearl Millet (Pennisetum Glaucum L.)", Research Journal of Agriculture et Biological Sciences 6(3), 176- 180

Amar, K.C., Chiranjit, M., Sabyasachi, S., Arijit, C. \& Elizabeth, N.P. (2015). "Synergic actions of polyphenols and cyanogens of peanut seed coat (Arachis hypogaea) on cytological, biochemical and functional changes in thyroid", Indian Journal of Experimental Biology 53, 143-151

Awada, S.H., Abedel, H., Edad, B., Hassan, M., Isam, A., Elfadil, E. \& Babiker (2005), “Antinutritional Factors content et Availability of Protein, Starch et Mineral of Maize (Zeamays linnaus) et lentil (Lens culinaris) As Influenced by Domestic Processing", Journal of food Technology 3(4), 523-528.

Boudjelal, A. \& Nancib, N. (2013), "Production d'Acide Lactique par Lactobacillus Rhamnosus sur Milieu à Base de Jus de Dattes, Revue des Energies Renouvelable : Production et Valorisation-Biomasse", 1, 42.

Dominic, A., James O.K., Fortune, A. \& Samuel, A.F. (2019), "Indigenous African fermented dairy products: Processing technology, microbiology and health benefits", Critical Reviews in Food Science and Nutrition $60(7), 1-16$

Drider, D.J. \& Prévoste, H. (2009), "Bactéries Lactiques physiologie, Métabolisme, Génomique et applications industrielles", Economica, 127-129.

Dubois, M., Gilles, K.A., Hamilton, J.K., Rebers, P.A \& Smith, F. (1956), "Colorimetric method for determination of sugars and related substances", Analytical Chemistry 28, 350-360.

Ejinkeonye, U.B., Nduka, O.C. \& Offia, O.B.I. (2018), "effect of fermentation duration on the nutritional and antinutritional content of watermelon seeds and sensory properties of their ogiri products", European Journal of Food Science and Technology 6(2), 1-16.

Ilesanmi, F.F. \& Opeyemi, O.S. (2017), "Production, nutritional and microbiological evaluation of Mahewu a South African Traditional Fermented Porridge", Journal of Advances in Biology \& Biotechnology 14(4), 110 .

Liu, S. (2003), "Practical implications of lactate and pyruvate metabolism by lactic acid bacteria in food and beverage fermentations", International Journal of Food Microbiology 83(2), 115-131.

Makawi, A.B., Mustafa, A.I., Adiamo, O.Q. \& Mohamed, A.I.A. (2019), "Effect of natural fermentation on the physicochemical, nutritional, functional, and microbiological properties of baobab (Adansonia digitata L.) fruit pulp flour", International Food Research Journal 26(6), 1707-1715

Makinde, F.M., Akinoso, R. \& Adepoju, A.O. (2013), "Effect of fermentation containers on the chemical composition of fermented sesame (Sesamum indicum L) seeds", African Journal of Food, Nutrition and Development 13(1), 7122-7137.

Marigo, G. (1973), "Sur une méthode de fractionnement et d'estimation des composés phénoliques chez les végétaux", Analusis 2,106-110.

Mohamed, M.E., Eltayed, Amro, B., Hassan, Mashier, A., Sulieman, Elfadil, E. \& Babiker (2007), "Effect of processing followed by fermentation on antinutritional factors content of pearl millet (Pennisetum glaucum L.) Cultivars", Paksitan journal of nutrition 6(5), 403-467.

Nawirska, A., Figiel, A., Kucharska, A.Z., Sokoł-Łetowska, A., \& Biesia, A. (2009), "Drying kinetics and quality parameters of pumpkin slices dehydrated using different methods", Journal of Food Engineering 94, 14-20.

Obadina, A.O., Akinola, O.J., Shittu, T.A. \& Bakare, H.A. (2013), "Effect of Natural Fermentation on the Chemical and Nutritional Composition of Fermented Soymilk Nono", Official Journal of Nigerian Institute of Food Science and Techonology, 31(2), 91-97

Ogodo, A.C., Ugbogu, O.C., Onyeagba, R.A. \& Okereke, H.C. (2019), "Microbiological quality, proximate composition and in vitro starch/protein digestibility of Sorghum bicolor flour fermented with lactic acid bacteria consortia", Chemical and Biological Technologies in Agriculture 6, 7.

Ojokoh, A.O. \& Orekoya, E.S. (2016), "Effect of Fermentation on the Proximate Composition of the Epicarp of 
Watermelon (Citrullus lanatus)", International Journal of Swarm Intelligence and Evolutionary Computation 5(3), 1-5

Pauwels, J.M., Van, R.E., Verloo, M. \& Mvondo, Y.A. (1992), “de laboratoire de pédologie", Agence Générale de la Coopération au Développement. Bruxelles, 265 p.

Ponka, R., Bouba, A.A., Fokou, L., Tambe, S.T., Beaucher, E., Piot M., Leonil, J. \& Gaucheron F. (2015), "Protein, mineral and amino acid content of some Cameroonian traditional dishes prepared from pumpkin (Cucurbita maxima Duch.)", Journal of Food Composition and Analysis 43, 169-174.

Settaluri, V.S. Kandala, C.V. K. Puppala, N. Sundaram, J. (2012), "Peanuts and Their Nutritional Aspect", Food and Nutrition Sciences 03(12), 1644-1650.

Sibomana, I.C., Sado K.S.L., Mashugalusa N.G., Ngang J.J.E. (2018). "Influence of chlorine and rosemary essential oil postharvest pre-treatments on quality parameters of fresh tomatoes during storage", Journal of Postharvest Technology 06(2), 57-68

Tchikoua, R. (2016), "Valorisation des bactéries lactiques isolées du grain et des pâtes de maïs fermenté : Biocontrôle d'Aspergillus flavus, d'aflatoxine B1 et effet sur la composition chimique des pâtes de maïs fermenté", Thèse de doctorat, Ecole national des sciences agro-industrielles, université de Ngaoundéré, 69161 .

Wang, P., Liu, J.C., \& Zhao, Q.Y. (2002), "Studies on nutrient composition and utilization of pumpkin fruit", Journal of Inner Mongolia Agricultural University 23, 52-54. 